\title{
ACCOUNTING PROCEDURE AND MANAGEMENT CASH WAQF IN INDONESIAN WAQF INSTITUTIONS
}

\author{
Laela Fitria Perdana ${ }^{*}$, Dewi Susilowati ${ }^{2}$, Christina Tri Setyorini ${ }^{3}$ \\ 1,2,3 Department of Accounting, Faculty of Economics and Business, Universitas Jenderal Soedirman \\ Jl. HR. Boenyamin No. 708, Purwokerto 53122, Jawa Tengah, Indonesia \\ *Email Correspondence : laelafp20@gmail.com
}

\begin{abstract}
This paper aims to explore the management and reporting of cash waqf in Indonesia Waqf Institutions. The methodology used in this study is qualitative descriptive research with case study approach to explain specifically about the management and reporting of cash Waqf. The results of this study indicate that the management of cash waqf in Dompet Dhuafa has fulfilled the waqf principle that adopted from the principle of BCPs corresponds to laws and regulations. On the contrary, at the Representative of Indonesian Waqf Board (BWI) in Banyumas Regency as the representative of waqf regulator, its management of waqf is not yet optimal. Dompet Dhuafa reports their waqf management in financial statement, while at Representative of Indonesian Waqf Board in Banyumas Regency did not report management of cash waqf.
\end{abstract}

Keywords: Waqf, Cash Waqf, Management, Accounting, Waqf Institution

\begin{abstract}
Abstrak
Penelitian ini bertujuan untuk mengeksplorasi dan memahami prosedur akuntansi dan pengelolaan wakafuang pada lembaga wakaf di Indonesia. Metode yang digunakan pada penelitian adalah deskriptif kualititatifdengan pendekatan studi kasus untuk menjelaskan secara spesifik mengenai pengelolaan dan pelaporan wakaf uang. Hasil penelitian ini menunjukkan bahwa pengelolaan wakaf uang di Dompet Dhuafa telah memenuhi prinsip wakafyang yang diadopsi dari prinsip BCPs sesuai dengan peraturan perundang-undangan yang berlaku. Sebaliknya, pada Perwakilan Badan Wakaf Indonesia (BWI) Kabupaten Banyumas sebagai perwakilan regulator wakaf, pengelolaan wakaf uang belum optimal. Dompet Dhuafa melaporkan pengelolaan wakaf uang pada laporan keuangannya, sedangkan pada Perwakilan BWI Kabupaten Banyumas, tidak melaporkan pengelolaan wakaf uang.

Kata Kunci: Wakaf, Wakaf Uang, Pengelolaan, Akuntansi, Lembaga Wakaf
\end{abstract}

\section{INTRODUCTION}

The society's economic problems and demands of economic prosperity in the twenty one century, waqf and its utilization have great potential in developing sharia economy and finance in Indonesia. In addition to waqf is one aspect of the spiritual teachings of Islam, waqf is also a teaching that emphasizes the importance of economic prosperity (Sambas, 2014). Generally, in Indonesia, Lack of society understanding about productive waqf makes waqf objects are not growing and less supported. Society recognize productive waqf as a giving in fixed assets, such as land, mosques, schools, orphanages, and graves. It has become one of caused productivity inhibiting waqf and unpopular (Mu'alim \& Abdurrahman, 2014). Thereby, the society takes consider twice to do waqf because according to them, waqf require high funds compared to zakah, infaq, and sadaqah. Whereas at this time, Nazhir has been developed another type of waqf asset, called cash waqf (money). MUI (2002) stated that cash waqf defined as waqf by a person, group and institutions or legal entities in the form of money (cash). Understanding money (cash) can be securities, such as stocks, checks and others. 
Potential of Cash Waqf in Indonesia is quite large as a country with largest population of Muslims in the world, so the effort to raise funds productive Cash Waqf is expected to run well. In addition, diversity of management of productive Cash Waqf can provide a wide field of jobs for the society, because it would require Nazhir who have professional skills related to the Waqf programs (DEKS Bank Indonesia - DES-FEB UNAIR, 2016). Other than that, Waqf Assets can be managed and developed so the benefits of waqf can increase and maintenance cost of Waqf Asset is not become society responsibility. Later on Mauquf Alaih is not only fakir, poor, unemployed, places of worship, social facilities, but also can be used for human resources development such as giving scholarships (Forum Ekonomi Islam Unsoed, 2017). Benefits option of productive Cash Waqf is quite diverse. Among them are Waqf of food, educational of Waqf, Waqf of health and economical of Waqf those can be utilized through the productive Cash Waqf (Global Wakaf, 2017). In Waqf of food, there are other kinds of benefits such as water Waqf, Waqf arranges in provision of wells and their supporting equipment to distribute appropriate water for consumption and used to community life.

Obstacles of productivity Cash Waqf is due to the decrease of public trust to the Official Waqf Institution (Republika, 2016). It is related to Waqf in Indonesia which is facing important problems, especially on its management and reporting. In fact, Waqf Institutions in Indonesia have not been managed with a professional framework, so they could not respond the needs of society (Republika, 2017). It is characterized by the lack of professionalism of Nazhir, so Waqf is not well managed and cannot provide welfare solutions. As one of strategies and role of the Government of Indonesia's attention in supporting Waqf of Indonesia is shown by enacting Law No. 41 Year 2004 on Waqf which is expected to be guidelines for Waqf Institutions in management and optimization of Waqf activities as religious institutions that have potential and economic benefits. Unfortunately this regulation still cannot respond the needs of the society because the Act does not regulate the calculation and accounting of Waqf. Nevertheless, Bank Indonesia (BI) and Otoritas Jasa Keuangan (OJK) as the supervisor, Ikatan Akuntan Indonesia (IAI) as the accounting profession, and Majelis Ulama Indonesia (MUI) are in process of arranging the appropriate accounting standards for Waqf (DEKS Bank Indonesia - DES-FEB UNAIR, 2016). Based on the facts of phenomena that have been described, researcher is interested to explore more deeply about Waqf management, especially Cash Waqf in Waqf Institutions. In addition to researcher also want to explore more deeply about the accounting, recording, and financial systems are used by Waqf Institution.

\section{LITERATURE REVIEW}

Waqf is derived from Arabic "Waqafa" (plural: awqāf) which means "to withhold" or "stop" or "keep quiet" or "stand still". In most cases, Waqf is defined as assets given by Wakif to Nazhir and then his assets is used its benefits for commonweal. Cash waqf is part of productive waqf which 
Accounting Procedure and Management Cash Waqf...

have differences with zakah, infaq and sadaqah, those are the existence of time constrains, the limit of the amount of fund paid, and the last is the current reward that God give to the contributors. On zakah, there is a provision regarding the due date of payment, to do Cash Waqf, Infaq, Sadaqa, there are no time limit, contributors can do anytime. The limit of the amount of fun paid on Zakah, for example, for Zakah income, the Zakah payer will pay it, if it has exceeded the equivalent of eighty grams of goods a year, but to do Cash Waqf, Infaq and Saqadah, do not have to wait until contibutors are rich, because the property is distributed through the provision of funds some people or parties. Then, the difereences between Cash Waqf, Infaq and Sadaqaf are in the benefits that receive by the receiver. For Cash Waqf, it has long term benefit, but for Infaq and Sadaqah only for that time to fulfill the receiver needs, for example give money to buy food for hunger one (DEKS Bank Indonesia - DES-FEB UNAIR, 2016). The legal basis of Waqf is not found in the Qur'an (QS Al-Hajj 22:77, QS Ali Imran 3:92, QS Al Baqarah 2:261) and Assunah. According to Law No. 41 Year 2004 article 6, Waqf can be implemented by fulfilling the elements of Waqf, there are Wakif, Nazhir, Cash Waqf, Declaration of Waqf, Allotment of Cash Waqf ad Period of Waqf.

As described above that Waqf Institutions in Indonesia have not been managed with a professional framework, Bank Indonesia arranges standard of waqf management by adopt 8 (eight) of 29 (twenty nine) principles of BCPs which existed and recognized in world (2012) by Bank for International Settlement (BIS) in Basel, Swiss. Those principles are relevant and appropriate to the characteristic of waqfs, they are 1) The Power of Law on Authority 2) Waqf Assets Classification and Nazhir License 3) Permitted Activities 4) Waqf Assets Management 5) Internal and External Control 6) Nazhir Governance 7) Financial Reports and Reporting Standard 8) Abuse of Waqf Assets and Financial Service. (DEKS Bank Indonesia - DES-FEB UNAIR, 2016).

\section{The Power of Law on Authority}

This principle emphasizes the regulatory system, effective and comprehensive management as stipulated in the Regulation of Waqf. These regulation of waqf into a solid legal basis which includes the existence of an independent authority. Authority has the authority to manage waqf. The authority is: Giving permission for the establishment of Nazhir, continuous monitoring of Nazhir, ensure that the implementation of Nazhir is in accordance with the law, and make corrections to Nazhir for better.

In Indonesia, the regulation on Waqf already exists, Law No. 41 Year 2004 on Waqf, Government Regulation No. 42 Year 2006 on the Implementation of Law No. 41 Year 2004 on Waqf, Regulation of the Minister of Religion No. 4 Year 2009 on Cash Waqf Registration Administration, and Decision of the Director General of Islamic Society No DJ.II / 420 Year 2009 on Model of Form and Specification of Cash Waqf Form. The Waqf rules show that Waqf regulations have been sufficiently thorough despite the need for improvement. 


\section{Waqf Assets Classification and Nazhir License}

The second principle regulate about assets of Waqf classification dan Nazhir license. Authorities must have asset mapping system arrangement for many different assets and each asset has a different economic impact. The clasification of Waqf assets can be divided by asset size, asset development potential, asset management, investment, profit sharing of Waqf project by using that asset. Criteria for making the asset classification should be considered.

\section{Permitted Activities}

The third principle regulate the allowed activities in the management of Waqfs. Allowed activities must have followed the sharia and legal laws of the country. Waqfs activities include collection, utilization, waqf assets and distribution of Waqf benefits. For example, Waqf stock, then there must be an investment rule that has a small risk, but still bring profit and follow the sharia rules. Collection of Waqfs should get approval about its sophistication. In the third principle is also regulated how the allocation of funds used Cash Waqf collected. The rules of Waqf priority should be clear so that the use of money is efficient and provides great benefits to Mauquf Alaih

\section{Waqf Assets Management}

The next principle of Waqf regulate is about the Waqf assets management. Wakif give assets to Nazhir accompanied designation. For example, Wakif wanted to the land Waqf to build school. Thus, Nazhir attempted to fulfill Wakif's request. Waqf asset management arrangement are categorized into six parts, namely: Collection, Utilization, Benefits Distribution of Waqf assets, Transfer, Transactions with Related Parties, and Risk Management. Waqf asset management and its relation to risk can be illustrated in the scheme contained in Figure 1. Waqf Asset Management Scheme.

\section{Internal and External Control}

This regulate is an approach taken by the Waqf authority associated with the control scheme carried out by the authorities to Nazhir. Authority control scheme must be integrated which includes the collection, utilization, managerial and distribution of Waqf asset benefits. Integration also includes the methodologies used by the authorities to assess and determine the risk of sharia aspects, management, in optimizing Waqf assets. This principle governs the technicalities and instruments used by the authorities to exercise control over the Nazhir. The Authority also evaluates the performance of the internal auditor, in so doing the authority is also entitled to use the external auditor as a third party to maintain objectivity. In addition, authorities are also entitled to require Nazhir report performance results to the authorities with timely and accurate, especially in the financial statements 


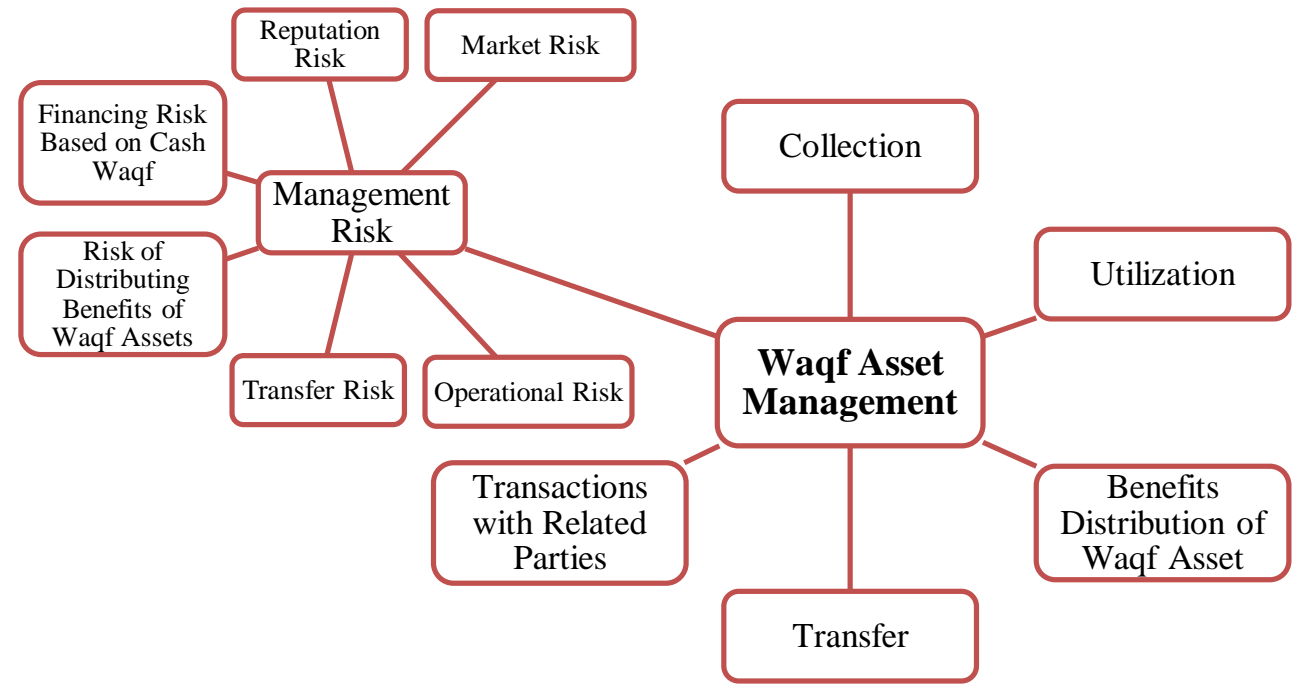

Figure 1. Waqf Asset Management Scheme

Source: (DEKS Bank Indonesia - DES-FEB UNAIR, 2016)

6. Nazhir Governance

On this principle, the authorities have full authority to make policies regarding the Nazhir criteria to ensure the optimization of wakaf assets. The fact that Waqf assets vary, from unproductive Waqf to productive Waqf. Both types of Waqf require different Nazhir, then the criteria are needed. Nazhir which has been authorized by the authority must carry out its duties well. Therefore, the authorities should create guidelines, whether specific or general about governance by Nazhir.

\section{Financial Reports and Reporting Standard}

This principle focuses on financial reporting and the importance of external financial auditors to control Nazhir, especially in reporting standards. This regulate requires the presence of an external auditor to audit the financial statements and ascertain the financial statements are in conformity with world-recognized accounting practices. This rule would make it easier for Nazhir to cooperate with foreign and local Nazhir. Nazhir in choosing an external auditor should consider the auditor's competence on his understanding of Waqf. The arrangement also focuses on the transparency, disclosure, and publication of reports covering all activities undertaken by Nazhir. Then, in order to improve the quality of financial statements, the authorities and institutions shall conduct a rigorous review of the reporting standards issued by Nazhir. 


\section{Abuse of Waqf Assets and Financial Service.}

This principle regulates Waqf abuse problems. The authorities must ensure that Nazhir does not commit disgraceful activities. For example, Nazhir conducted operations by bringing in funds from abroad, but after funds reached Indonesia, Nazhir abused the funds.

The accounting system is the organizational forms, records, and reports are coordinated in such a way as to provide the financial information needed by management in order to facilitate the management of the company (DEKS Bank Indonesia - DES-FEB UNAIR, 2016). From the definition can be said that the accounting system is a recording system that produces financial report. The information presented in the financial statements of Waqf Institutions is general, in the book which tittle Wakaf: Pengaturan Tata Kelola yang Efektif (2016) (DEKS Bank Indonesia DES-FEB UNAIR, 2016) according Kustiawan et al (2012: 28), define a form of financial statements zakat institution to be adopted for the financial statements Waqf Institutions, as follows: Amount and nature of assets, liabilities, and proceeds of Waqf; The effect of transactions, events, and other situations that change value and the nature of the equity proceeds; The type and amount of inflow and outflow of resources in one period and the relationship between both; The Nazhir method to obtaining and spending cash and other factors affecting liquidity; Nazhir Compliance to the provisions of sharia and information of acceptance that is not in accordance with the provisions of sharia when it exists and how such revenue is obtained and disbursement; The level of results management and development of Waqf gained PSAK 109 requires amil zakat to disclose transactions related to zakat. Thus, Nazhir as the manager and developer of Waqf also have the same obligations related to Waqf transactions, not limited to the following:

a. Distribution policy of Waqf result, such as determining the priority scale of distribution, and the recipient;

b. Distribution policy of Waqf result for beneficiaries, such as percentage sharing, reason, and policy consistency;

c. The method to determining the fair value for the receipt of Waqf in non-cash assets

d. Details of the amount of Waqf funds distribution covering the total management expenses and the amount of funds received directly by each beneficiary;

e. A special relationship between Nazhir, and the beneficiaries which include: the nature of the special relationship, the amount and type of benefits and the percentage of the Waqf proceeds distributed from the total distribution during the period.

The types of information should be reported and audited in the form of financial statements on a regular basis, such as: Balance Sheet (Financial position Statement), Fund changes statement, Changes in assets under management Statement, Cash flows statement, Financial statements notes. 
Accounting Procedure and Management Cash Waqf...

\section{RESEARCH METHODOLOGY}

Research used qualitative method with case study approach. Qualitative research attempted to illustrate the true illustration of the phenomenons occurring in Waqf accounting and management in Indonesia Waqf Institutions. Case study approach used in reseach aims to explain the specific in identifying phenomenons. Research conducted in Dompet Dhuafa Purwoketo and Indonesian Waqf Board. Subjects of research are selected through purposive sampling procedure based on the availability of structure and financial report in Waqf Institution. Data collection method used in research is interview, observation, and document analysis. Interview is a method where researcher as interviewer conduct an interview with informants as interviewees to collect data. Then, Observation is a method to observe research object and document analysis method used to complete the data through document. According to (Creswell, 2012), data analysis in qualitative research will be hand-in-hand with other sections in the development of qualitative research, namely data collection and writing of findings. In this reseach, data analysis used Data Reduction, Data Display, and Conclusion: Drawing or Verifying. Validity is one of strengths of qualitative research and is based on determination of whether findings are accurate from point of view of researcher, participants, and readers (Creswell, 2012). Creswell (2012) revealed there are eight main strategies for assessing accuracy of findings, but researcher use only three strategies in assessing accuracy of findings, they are triangulation, member checking and spend longer time in the field.

\section{RESULT AND DISCUSSION}

\section{An Overview of Dompet Dhuafa}

Dompet Dhuafa Republika is a non-profit institutions owned by Indonesia people who are solemn to raise the social worth of humankind of dhuafa with Ziswaf funds (Zakat, Infaq, Shadaqah, Waqf and other halal and legal funds, from individuals, groups, companies/institutions). The establishment of Dompet Dhuafa begins with empathy of journalist community which is interacted with poor, and also rich people. Then, it was initiated a fundraising joint for caring dhuafa. Four journalists and initiators are Parni Hadi, Haidar Bagir, S. Sinansari Ecip and Eri Sudewo combined as the Board of Founders of independent institutions Dompet Dhuafa Republika. Dompet Dhuafa was founded on September 4, 1994 by four founders, they are Parni Hadi, Haidar Bagir, S. Sinansari Ecip and Eri Sudewo with Ziswaf activities. Since then, Dompet Dhuafa Foundation has been actively collecting and distributing Ziswaf funds on the basis of caring through humanitarian programs, especially disaster relief in health, education and economy. Dompet Dhuafa professionalism is increasing in line with the expansion of its programs, 
so that on September 14, 1994, Dompet Dhuafa was listed in the Department of Social Affairs as an organization in the form of Foundation. The formation of the foundation is conducted in the presence of Notary H. Abu Yusuf, S.H. and announced in the State Gazette of the Republic of Indonesia No. 163 / A.YAY.HKM / 1996 / PNJAKSEL.

On 8 October 2001, the Minister of Religious Affairs issued Decree No. 439 of 2001 on the Confirmation of Dompet Dhuafa Republika as the National Amil Zakah. It proves that the spirit of humanity and professionalism is getting stronger year to year. Besides, Dompet Dhuafa realized which is in addition to zakat, waqf also has a high potentials. Meanwhile, until present, the management of waqf is not yet optimal and managed effectively and professionally. On July 14, 2005, Dompet Dhuafa established Tabung Wakaf Indonesia (TWI) as Nazhir of Dompet Dhuafa as a form of commitment in developing waqf resources to be managed productively and support the development of social programs and economic empowerment which has been implemented through the management of zakat resources, infaq and sadaqah safely and professionally. Through Tabung Wakaf Indonesia, Dompet Dhuafa Republika Foundation has also been registered in Indonesian Waqf Board as Nazhir on June 16, 2011, with registration number 36.74.3.1.0000.1 referring to Law No. 41 Year 2004 on Waqf. In addition, Dompet Dhuafa Foundation has also been listed as the Nazhir cash waqf Nazhir on Indonesian Waqf Board on February 10, 2015 with registration number 3.3.00100.

\section{An Overview of Indonesian Waqf Board}

Indonesian Waqf Board is an independent state institution to develop waqf in Indonesia which in the execution of its tasks are free from the influence of power and is responsible to the community. The establishment of Indonesian waqf Institution itself is a form of the realization of Law No. 41 Year 2004 on Waqf. In Law No. 41 Year 2004 Article 47 states that the Indonesian Waqf Board is established in order to promote and develop national waqf. Indonesian waqf Institution membership for the first time was appointed and approved by the President of the Republic of Indonesia on July 13, 2007 in accordance with Presidential Decree no. 75 / M in 2007.

Regulation of Indonesian Waqf Board No. 2 Year 2012 about Representative of Indonesian Waqf Board stipulates that Indonesian Waqf Board may establish the Representative of Indonesian Waqf Board in the Provincial Capital and Representative of Indonesian Waqf Board in Regency/City domiciled in the Capital City of Regency/City. Representative of Indonesian Waqf Board in Banyumas Regency is located in Banyumas Regency which was formed on October 10, 2016 as a request to form Representative of Indonesian waqf Board in Banyumas Regency on July 11, 2016 by the Head Office of the Ministry of Religious Affairs of Banyumas Regency. Representative of Indonesian waqf Board in Banyumas Regency was formed to overcome the 
Accounting Procedure and Management Cash Waqf...

problems of waqf, especially the problems of waqf land. In the implementation of Representative of Indonesian Waqf Board in Banyumas Regency has task and authority as regulated in Regulation of Indonesian Waqf Board No. 2 Year 2012 on Representative of Indonesian Waqf Board, as follows:

1. Implement Indonesian Waqf Baord policies and tasks at the regency/cities level

2. Coordinate with ministries and agencies in the implementation of Indonesian Waqf Board regency/cities.

3. Guiding Nazhir in managing and developing waqf assets of regency/city.

4. To act and responsible for and on behalf of Representative of Indonesian Waqf Board in regency/cities both inside and outside.

5. Dismissals and replacing Nazhir when the wide of waqf land is less than $1000 \mathrm{~m}^{2}$ (thousand square meters)

6. Publishing Receipts of Nazhir Registration of the waqf land area is less than $1000 \mathrm{~m}^{2}$ (thousand square meters)

7. Surveying and reporting on the proposed changes of waqf asset allotment in the form of land of less than $1000 \mathrm{~m}^{2}$ (one thousand meters per square).

8. Surveying and reporting on the proposed exchange /change of waqf asset status (ruislagh) in the form of land of an area less than $1000 \mathrm{~m}^{2}$ (one thousand meters per square)

9. Carry out other tasks provided by the Provincial BWI Representative.

\section{Data Analysis}

The results of this study indicate that the management of cash waqf in Dompet Dhuafa has fulfilled the waqf principle that adopted from the principle of BCPs: 1) The Power of Law on Authority 2) Waqf Assets Classification and Nazhir License 3) Permitted Activities 4) Waqf Assets Management 5) Internal and External Control 6) Nazhir Governance 7) Financial Reports and Reporting Standard 8) Abuse of Waqf Assets and Financial Service that corresponds to laws and regulations. On the contrary, at the Representative of Indonesian Waqf Board (BWI) in Banyumas Regency as the representative of waqf regulator, its management of waqf is not yet optimal.

In the Power of Law on Authority Princple, the compliance of Tabung Wakaf Indonesia as Nazhir to manage and develop cash waqf corresponding to regulation which applied that marked by registration of Tabung Wakaf Indonesia as Nazhir of cash waqf to Indonesian Waqf Board. Registration follows stipulated of Law No. 41 Year 2004 Article 14, Government Regulation No. 42 Year 2006 Article 11 and Regulation of Minister of Religious Affairs No. 4 Year 2009 Article 1 Paragraph 4 that Nazhir of waqf should be registered in Ministry of Religion and Indonesian Waqf Board. Moreover, Tabung Wakaf Indonesia as Nazhir also publishing cash waqf certificate to the Wakif who do waqf corresponds to Regulation of Minister of Religious Affairs No. 4 Year 2009 Article 3 and Regulation of Indonesian Waqf Board No. 01 Year 2009 Article 3. While in 
Representative of Indonesian Waqf Board inBanyumas Regency claimed runs those regulation even not comprehensive yet, as Vice Chairman said that Indonesian Waqf Board Representatives of Banyumas regency established to solve waqf issues, especially land waqf and currently has not received letter of assignment to manage cash waqf.

In Waqf Assets Classification and Nazhir License Principle, Tabung Wakaf Indonesia has arranged classification of cash waqf, involve: Money, Gold and silver, Dinar and dirham Gold and silver jewelry Stock Cash waqf classification corresponds to the definition of movable property which is in Law No. 41 Year 2004 Article 16 Paragraph 3. For the management, cash waqf assets are categorized to 7 (seven) classifications to make it easier to manage, they are:

1. Social property; used directly to social programs need Portofolio: 1) RS. Rumah Sehat Terpadu Dompet Dhuafa, RS. AKA Medika Sribhawono, 2) Masjid SMART Sekolah Semen Cibinong, 3) Masjid Al Madinah

2. Commersial property; based on rent Portofolio: 1) Philanthopy Building

3. Social business; based on business management Portofolio: 1) Sekolah Islam Al-Syukro Universal

4. Farm; planted with trees whose harvest period is not more than 5 (five) years and beneficial plants.

Portofolio: 1) Pabrik Ekstrak Buah Indonesia Berjaya

5. Ruilslag; unproductive buildings and land

6. Capital market securities (Stock); based on risk management analysis of capital market by emphasizing sharia principle, fundamental companies and potential dividends..

7. Vehicle

Classification of cash waqf assets management later on distributed its management benefits into 2 (two) categories, those are 1) Economic welfare such as agriculture, farm, and stock, 2) Social welfare such as education, health, and mosque.

In the Permitted Activities Principle, Tabung Wakaf Indonesia has 2 (two) division, they are fundraising divison and assets management division. Fundraising division in raising funds do offers to community through the corporation, community, social network, open booth, one by one by offers waqf programs to prospective Wakif and also launch movement such as Gerakan Satu Juta Wakif. After funds collected and transfered to fundraising division's account will also transfered to account of shelter managed by dinance division. Funds are submitted to assets management division to be managed its business development in accordance to its allocation. Those activities should be approved by Sharia Board of Dompet Dhuafa in order its implementation is in accordance with Islamic ethics and still bring profit in the sharia corridor. In the other hand, the Chairman of Representative of Indonesian Waqf Board said that Indonesian 
Accounting Procedure and Management Cash Waqf...

Waqf Board Representatives of Banyumas regency is not a Nazhir who manage waqf because there is no letter of assigment to be a Nazhir, moreover, DR. Supani, MA said that Representative of Indonesian Waqf Board is a non-government institution, there is no budget. Thus, the implementation of waqf management has not gone well. In Law No. 41 Year 2004 Article 59 stated that in the performing duties of Representative of Indonesian Waqf Board, Government is obliged to assist its operational costs. More details about the financing of Indonesian Waqf Board is in Government Regulation No. 42 Year 2006 Article 52 Paragraph 1 which stated that Indonesian waqf Board financing assistance is charged to APBN for the first 10 (teen) years through Ministry of Religious Affairs budget and can be extended. Those researcher's findings cause the researcher is questioning whether Indonesian waqf Board lacks of and/ or have not understood the exciting regulations or there is lacking of coordination between Indonesian Waqf Board and its representatives. So, operational of Indonesian waqf Board Representatives in Banyumas Regency is not going well.

In the Waqf Assets Management Principle, Tabung Wakaf Indonesia collaborates with Dompet Dhuafa Enterprise in managing waqf assets. Zona Madina is a community empowerment area which is integrated and sustainable performing. Zona Madina Area is built above $8.5 \mathrm{H} \mathrm{waqf}$ land in Parung, Bogor. Zona Medina Area concists of several programs of empowerment activities and community services whose management are sourced from ziswaf funds. Management program based on waqf funds are Sekolah Smart Ekselensia, DD University, RS. Rumah Sehat Terpadu, and Masjid Al Madinah. Rumah Sehat Terpadu Hospital is one example of cash waqf program managed by Dompet Dhuafa in Zona Madina Area. Rumah Sehat Terpadu Hospital is built on unproductive empty waqf land and its development based on survey of the hospital potential there. Surroundings of fthe hospital, many dhuafa rejected by hospital because the hospital does not have operational cost at the beginning. Therefore, Dompet Dhuafa took initiative to set up RSCM class hospital for free for the dhuafa. It corresponds to Law No. 41 Year 2004 Article 42 and 43. An example of managing a cash waqf assets in Dompet Dhuafa is figured in the scheme which is the result of the researcher's analysis of the interview data conducted with Sunarto (March 23, 2018) on Figure 2. An Example of Fundraising and Waqf Management Scheme In Rumah Sehat Terpadu Hosital. 


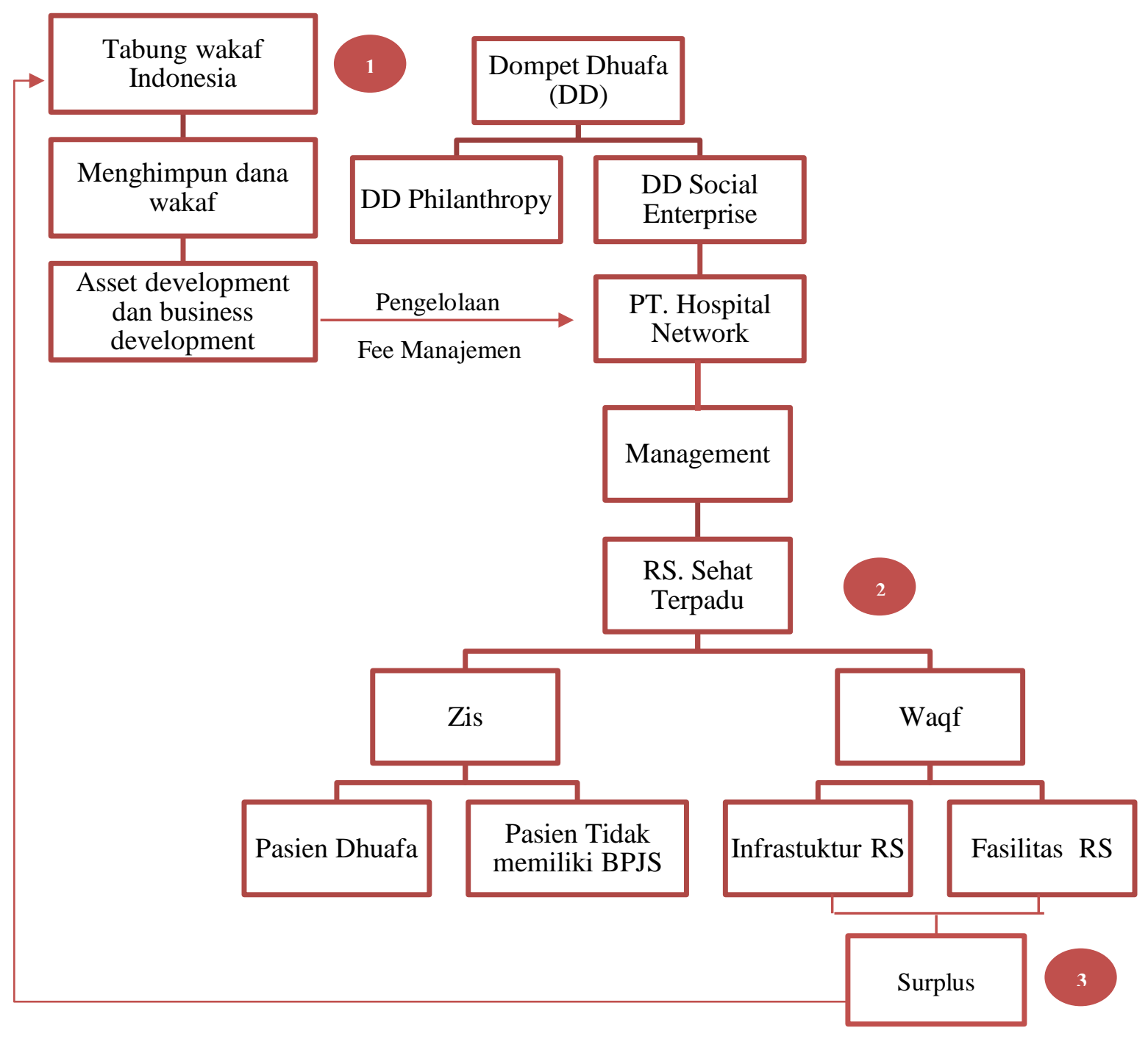

Figure 2. Fundraising and Waqf Management Scheme

In the Internal and External Control Principle, internal control in the Tabung Wakaf Indonesia (TWI) in the form of human resource control and asset control which is supervised directly by the Director of TWI. Human resource control is conducted on the fundraising and asset management divisions, whether the task has been carried out in accordance with the provisions of TWI. Asset control is performed considering the number of waqf assets managed by TWI. It is said that as Nazhir, TWI must be trustworthy and transparent to the community. In addition to internal controls, Nazhir also gets external control by public accountants. Waqf assets managed, then recorded and reported in the form of financial statements and external control by a designated public accountant. This is performed to assess the accountability of Dompet Dhuafa in managing the waqfassets mandated. In Law No. 41 Year 2004 Article 65 states that in the implementation of supervision, the Minister may use public accountant. Meanwhile, In the interview process, the Chairman and Vice Chairman of Indonesian Waqf Board Representatives of Banyumas regency states a suprising statement that they do not know who's become Nazhir of cash waqf in Banyumas Regency. With the findings of this researcher, the researcher questioned how the 
Accounting Procedure and Management Cash Waqf...

functions, duties and authority of Representative of Indonesian waqf Board in Banyumas Regency about Nazhir and why Representative of Nazhir of Dompet Dhuafa can perform operational management of cash waqf, but Representative of Indonesian Waqf Board in Banyumas Regency as representative of waqf authority in Banyumas Regency can not do guide against Nazhir. Because according to Regulation of Indonesian Waqf Board No. 2 Year 2012 Article 5 Paragraph 2 Number 3 is to guide Nazhir in managing and developing waqf assets. In addition, the researcher also questioned how the relationship exists between Indonesian waqf Board and its representative, because according to Law No. 41 Year 2004 Article 48 that Indonesian Waqf Board is domiciled in the capital of the Unitary State of the republic of Indonesia and may establish representation in the province and/ or regency/city as required.

In the Nazhir Governance Principle, Tabung Wakaf Indonesia has two main division, Fundraising Division and Asset Management Division. Every staff who assist to manage cash waqf, he/she will through several steps. If he/she is placed in asset management division, at least he/she knows about financial management, operational and management cash waqf. Then, if he/she is placed in Fundraising Division, he/she have to fulfill Nazhir's stipulation, also who arrange policy, he/she has to capability about regulation understanding and asset legality. Dompet Dhuafa has institute values that is INSPIRATION stands for Islami (islamic), Universal (universal), Peduli (caring), Inovatif (inovative), Responsif (responsive), Amanah (trusted), Profesional (professional). It indicates that the Chairman has created a culture and code of ethics of Islam. In the selection of staff who will assist Nazhir in managing the waqf must pass several stages. In Tabung wakaf Indonesia there are two divisions, namely fundraising division and asset management division. If staff will be placed in the asset management division, then at least he must understand about financial management, operations and management. In addition, the Chairman of Dompet Dhuafa also made a policy that the stakeholders and all administrators have no rights over the assets managed, even the founder of Dompet Dhuafa Republika though. This is performed so that when the stakeholders and managers have been out of their tenure, or died, the heirs cannot claim assets that are managed. Because the managed assets belong to the people, not private assets. Meanwhile, Organizer of Representative of Indonesian Waqf Board in Banyumas Regency has other professions and cannot work maximally in Representative of Indonesian Waqf Board in Banyumas Regency.

In the Financial Reports and Reporting Standard Principle, Tabung wakaf Indonesia to resolve the unavailability of waqf accounting standards by reported the management of waqf refers to PSAK 109, the accounting standard of zakah. While at the Representative of Indonesian Waqf Board in Banyumas Regency, the operation uses individual funds due to the absence of budget from the government. Through the documents analysis which is researcher do, researcher found on the website BWI (www.bwi.or.id) accessed on March 20, 2018 At 20:57 pm that Indonesian Waqf Board has 7 (seven) years did not upload reporting of cash waqf management because the last uploaded Report in 2011. 
With the findings of researcher, researcher's questioning how is Indonesian Waqf Board accountability to the management of waqf to the community.

In the Abuse of Waqf Assets and Financial Service Principle, Until present, Dompet Dhuafa and Indonesian Waqf Board did not commit abuse of waqf assets and financial services.

Dompet Dhuafa reports their waqf management in financial statement is using PSAK No. 45 Revised 2011 "Non-Profit Entities Financial Reporting" and PSAK No. 109 "Accounting for Zakat and Infak/Saqadah". While at Representative of Indonesian Waqf Board in Banyumas Regency did not report management of cash waqf.

In Dompet Dhuafa financial statements, waqf is presented in one account, there is no separation between waqf in other form and cash waqf (money), so the numbers cannot be known for sure. The acceptance of the cash waqf is acknowledged when it is received by Nazhir (received from Wakif by Nazhir and published certificate of cash waqf), the calculation uses the rupiah value, the recognition of the cash waqf is recorded in the statement of financial position as the balance of funds (permanently restricted support waqf, restricted support waqf). Permanentky restricted support waqf is fund that can only be used for things related to waqf, while restricted support waqf is fund that can be used for things determined before. Then when cash waqf is invested, cash waqf is recognized when profit sharing is given, the measurement uses the rupiah value, the recognition is recorded in the statement of financial position as revenue profit sharing. The distribution of cash waqf is recognized when the cash waqf is distributed, the measurement using rupiah value and its disclosure are disclosed in the statement of financial position as assets under management and management of waqf assets. In the financial statements are not explained what is the difference between asset management and management of wakaf assets. The financial statements prepared by Dompet Dhuafa include: Statements of Financial Position provides information about asset, liabilities, net asset and information about relation among these elements at any given time, statements of Activities provides information about the effect of transactions and other activities that change the amount and characteristic of net assets, relation among transactions and other activities and how's using of resources in the implementation of the programs, statements of Fund Changes provides report on changes in Waqf funds, Nazhir funds, and non-halal funds, both from the collection and income of waqt proceeds; statements of Asset Change Under Management provide information of changes in assets under management statement, starting from current assets, non-current assets, and accumulated depreciation, additions and deductions, beginning balance and final balance; Statements of Cash Flows provides information for users of financial statements which resulted in cash and cash equivalents and Nazhir need to use those cash flows. The cash flow statement covers the entire cash flows in operating, investing and financing activities in one period; 
Accounting Procedure and Management Cash Waqf...

Notes to Financial Statement is a various notes that present financial statements to provide more detailed information about Nazhir, Nazhir's accounting policies, explanation of key posts and human resource development efforts.

\section{CONCLUSION}

From the discussion in the previous chapter we can take some conclusion that Cash waqf management in Dompet Dhuafa corresponds to Government regulation based on BCPs principle, they are 1) The Power of Law on Authority 2) Waqf Assets Classification and Nazhir License 3) Permitted Activities 4) Waqf Assets Management 5) Internal and External Control 6) Nazhir Governance 7) Financial Reports and Reporting Standard 8) Abuse of Waqf Assets and Financial Service. While, cash waqf management in Indonesia Waqf Board Representative still needs an evaluation because the execution of tasks are not running properly, such as there is no budget for operational activities in the Representative of Indonesian Waqf Board in Banyumas regency. Accounting system, recording and reporting standard used for cash waqfs in Dompet Dhuafa is arranged corresponds to PSAK No. 45 Revised 2011 "NonProfit Entities Financial Reporting" and PSAK No. 109 "Accounting for Zakah and Infaq/Sadaqah". While, in Representative of Indonesian Waqf Board in Banyumas Regency does not report their task implementation in developing cash waqf and guide Nazhir of cash waqf. It caused by ignorance of Indonesia Waqf Board of cash waqf Nazhir in Banyumas regency.

There are several implications for better accounting and management cash waqf. For cash waqf management in Representative of Indonesian Waqf Board in Banyumas Regency as waqf authority representative in Banyumas Regency is obliged to guidance Nazhir development for cash. This is in accordance with Law Number 41 Year 2004 Article 49 Paragraph 1 (a). Representative of Indonesian Waqf Board in Banyumas Regency as waqf authority representative in Banyumas Regency established by the Government, should get a budget to implement the operational of waqf development, espesialy cash waqf. It corresponds to Law Number 41 Year 2004 Article 59 and Government Regulation Number 42 Year 2006 Article 52 Paragraph 1. Then, need an evaluation about Nazhir of Indonesia Waqf Board. It is in accordance with Law No. 41 of Article 1 Paragraph 7 stated that the Indonesian Waqf Board is an independent institution to develop waqf in Indonesia. Whether the independence is not disrupted if the Indonesian Waqf Board as a waqf authority, also as Nazhir. Last, needs a coordination between the head of Indonesian WaqfBoard and the representative of Indonesian WaqfBoard in Banyumas Regency about anyone who is Nazhir of cash waqf Banyumas Regency. It corresponds to Representative of Indonesian Waqf Board No. 2 Year 2012 Article 5 Paragraph 2 number 3. If representative of nazhir of Dompet Dhuafa can implement cash waqf management, why representative of Indonesia Waqf Board in Banyumas regency cannot do guide the Nazhir. For the accounting system, recording and reporting standard used for cash waqf in Waqf Institution, Representative of Indonesian Waqf Board in Banyumas Regency is obliged to report the task implementation of cash waqf development to society. It 
corresponds to Law Number 41 Year 2004 Article 61. And in Dompet Dhuafa, Waqf asset management program reporting can be supported using conventional accounting standards. It is related to the recognition of the waqf asset value, for example the building asset value of the Rumah Sehat Terpadu Hospital.

Based on the research results, here are some limitations in this research. This research was only conducted in one (1) waqf institution. So it does not have a comparison and does not reflect the waqf management in Indonesia widely. For further research, it can be performed at several other waqf institutions. Waqf authority representative, namely Indonesia waqf board representative of Banyumas Regency is still 1 (one) year old. So, researcher founds some findings of the tasks implementation that has not run properly. For further research, research can be performed on finding of waqf development in the head or provincial representative of Indonesian Waqf Board for a wider explanation.

\section{REFERENCE}

Abdurrahman, M. M. (2014). Activating Money (Cash) Waqf as an Effort to Increase Community Welfare.

Ascarya. (2017). Integrasi Keuangan Komersial dan Sosial Islam - Usulan Model. Jakarta: Departmen Ekonomi dan Keuangan Syariah - Bank Indonesia.

Badan Wakaf Indonesia. (2007, December 27 Thursday). Diambil kembali dari http://bwi.or.id/index.php/in/wakaf-uang-tentang-wakaf-57.html

Badan Wakaf Indonesia. (2009). Peraturan Badan Wakaf Indonesia Nomor 01 Tahun 2009.

Badan Wakaf Indonesia. (2010). Peraturan Badan Wakaf Indonesia Nomor 4 Tahun 2010.

Badan Wakaf Indonesia. (2012). Laporan Wakaf Uang di BWI. Diambil kembali dari Badan Wakaf Indonesia: http://bwi.or.id/index.php/in/unduhan.html?task=finish\&cid=39\&catid=2\&m=0

Creswell, J. W. (2012). Educational Research: Planning, Conducting, and Evaluating Quantitative and Qualitative Research.

DEKS Bank Indonesia - DES-FEB UNAIR. (2016). Wakaf: Pengaturan dan Tata Kelola yang Efektif. Jakarta: Departemen Ekonomi dan Keuangan Syariah - Bank Indonesia

Detik Travel. (2017). Diambil kembali dari https://travel.detik.com/traveladdict/negerimuslim

Dirjen Bimas Depag RI. (2013). Pedoman Pengelolaan dan Perkembangan Wakaf. Jakarta.

Dirjen Bimas Islam Depag RI. (2006). Fiqih Wakaf. Jakarta.

Forum Ekonomi Islam Unsoed. (2017). Materi Wakaf.

Global Wakaf. (2017). Diambil kembali dari https://globalwakaf.com/

Hanifa, A. C. (2015). The Sharia-compliance of Financial Reporting Practices: A Case Study on Waqf.

Ihsan, H., \& Ibrahim, S. H. (2011). Waqf Accounting and Management In Indonesia Waqf Institution. 
Kementerian Agama. (2009). Peraturan Menteri Agama Republik Indonesia Nomor 4 Tahun 2009.

Kompas. (2017, Agustus). Diambil kembali dari http://ekonomi.kompas.com/read/2017/08/24/111037826/sri-mulyani-dana-wakaf-bisadimanfaatkan-untuk-pendanaan-pembangunan

Kompasiana. (2016, November ). Diambil kembali dari https://www.kompasiana.com/dzikriramadhan/dampak-masifkorupsi 581edb5609b0bd514f471e73

Masruki, R., \& Shafii, Z. (2013). The Development of Waqf Accounting in Enhancing Accountability.

Miles, M. B., \& Huberman, A. M. (2009). Analisis Data Kualitatif: Buku Sumber Tentang Metode-metode Baru. Jakarta: Penerbit Universitas Indonesia (UI-Press).

Mu'alim, M., \& Abdurrahman. (2014). Activating Money (Cash) Waqf as an Effort to Increase Community Welfare.

MUI. (2002). Fatwa Tentang Wakaf.

Mulyadi. (2003). Sistem Akuntansi. Jakarta: Salemba Empat.

Munir, A. S. (2015). Optimalisasi Pemberdayaan Wakaf Secara Produktif.

Noordin, N. H., Haron, S. N., \& Kassim, S. (2015). Developing a Comprehensive Performance Measurement System for Waqf Institutions.

Republik Indonesia. (2004). Undang-undang Nomor 41 Tahun 2004 Tentang Wakaf.

Republik Indonesia. (2006). Peraturan Pemerintah Republik Indonesia Nomor 42 Tahun 2006.

Republika. (2016, May). Diambil kembali dari http://www.republika.co.id/berita/dunia-islam/islamnusantara/16/05/12/o72bm8394-pemahaman-wakaf-produktif-dinilai-minim

Republika. (2017, November Thursday). Diambil kembali dari http://www.republika.co.id/berita/ekonomi/syariah-ekonomi/17/11/09/oz5hje423-agarlembaga-wakaf-lebih-profesional

Sambas, A. (2014). Development of Waqf Management in Indonesia: Potency and Challenge.

Siswantoro, D., Haula, R., \& Fatthurahman, H. (2016). Redefinition of Cash Waqf (Endowment) Terminology in the Indonesian Context: A Comparison with Malaysia and Singapore.

Sonhaji, H. A. (2016). Bahagiamu Lengkap Dengan Wakaf. Banten: DD Publishing.

Tooraman, C., Tuncsiper, B., \& Yilmaz, S. (2004). Cash Awqaf in the Ottomans as Philanthropic Foundations, and their Accounting Practices.

Wijaya, I. (2015). Pengelolaan dan Pelaporan Aset Wakaf Pada Lembaga Wakaf di Indonesia (Studi Kasus Pada Yayasan Badan Wakaf Sultan Agung). 